\title{
Optimal Management Energy System and Control Strategies for Isolated Hybrid Solar-Wind-Battery-Diesel Power System
}

\author{
F. E. Tahiri ${ }^{1 *}$, K. Chikh ${ }^{1,2}$, M. Khafallah ${ }^{1}$ \\ ${ }^{I}$ Energy and Electrical Systems Laboratory, Hassan II university-ENSEM Casablanca, Casablanca, Morocco \\ ${ }^{2}$ Science and Technology for the Engineer Laboratory, Sultan Moulay Slimane University -ENSA Khouribga, Casablanca, Morocco
}

\begin{abstract}
This paper proposes optimal control strategies of a standalone Hybrid Power System (HPS) to supply sustainable and optimal energy to an isolated site with improved quality of electrical energy. A topology of Isolated Hybrid Power System (IHPS) is proposed, consists of: a Photovoltaic System (PVS), a Wind Energy Conversion System (WECS), electronic power devices controlled to maximize energy production from renewable sources and to maintain the constant DC-link voltage, a Battery Energy Storage System (BESS), Diesel Generator (DG), and a Pulse Width Modulation (PWM) Voltage Source Inverter (VSI) located at the load-side end. In addition, a novel control strategy has been proposed, in this work, to maximize the power from the PVS. This presented strategy, based on the combination between Perturb and Observe (P\&O) algorithm and the Fuzzy PI Controller (FPIC), presents a good performance, especially in the dynamic state compared to the classical algorithm $\mathrm{P} \& \mathrm{O}$. A supervisory control algorithm has been elaborated to manage the energy flows between the devices of the hybrid system to make the decision of the optimal operating mode in order to ensure a continuous supply of the load with minimum usage of batteries and DG. The simulation results developed in the Matlab/Simulink environment are applied to show the efficiency and performance of the proposed control strategies in terms of power optimization and energy management.
\end{abstract}

\section{Keywords:}

Photovoltaic System (PVS);

Wind Energy Conversion System (WECS);

Battery Energy Storage System (BESS);

Diesel Generator (DG);

Isolated Hybrid Power System (IHPS);

Fuzzy PI Controller (FPIC).

\section{Article History:}

Received: 16 December 2020

Revised: $\quad 12$ February 2021

Accepted: 20 February 2021

Published: $01 \quad$ April 2021

\section{1- Introduction}

In the last decade, the exhausting fossil fuels and increasing electrical energy demand are the huge issues on the international agenda. This has led to developing renewable energy sources (RES) from natural free resources (solar radiation, wind speed, tides or waves etc.), inexhaustible, available in all regions and respectful of the environment [1]. Many remote parts on the world are not electrified. To provide electricity in such remote places, the efficient use of RES is becoming very much suitable from both the technical and economic points of view. The electrification of isolated sites can be established either by one RES or hybrid RES. Most common combination used in the RES is the solar photovoltaic with the wind energy sources, due to their complementarity.

However, other sources of energy can be implemented (storage system, diesel generator) with the hybrid renewable energy system (HRES), to ensure a continuous power supply in case of unavailability of power production from the RES. The main problem in operating standalone HRES is to be able to supply the energy requested by the consumer despite the large variations in the produced power by RESs, caused by the variation of weather conditions, while maintaining the frequency and the voltage supplied to consumers within acceptable limits $[2,3]$.

\section{* CONTACT: Fatima-ezzahra.tahiri@ensem.ac.ma}

DOI: http://dx.doi.org/10.28991/esj-2021-01262

(C) 2021 by the authors. Licensee ESJ, Italy. This is an open access article under the terms and conditions of the Creative Commons Attribution (CC-BY) license (https://creativecommons.org/licenses/by/4.0/). 
To overcome this weakness, this presented work proposes control strategies, to make the IHPS more reliable and cost effective with improved power quality. This research is organized as follows: section 2 describes the structure of the proposed IHPS. Section 3 presents the modelling of IHPS sources. The different controls applied to power electronics interfaces are introduced in section 4. Section 5 is dedicated to the supervisory control strategy IHPS components. Section 6 represents the necessary simulation results. Finally, a conclusion of the study is stated in section 7.

\section{2- Description of the Studied IHPS}

The proposed topology of the IHPS studied consists: two RESs (PVS integrated with WECS), storage system, diesel generator and power electronic devices as shown in Figure 1. This configuration is known by its technical-economic advantages in supplying energy for isolated areas [4].

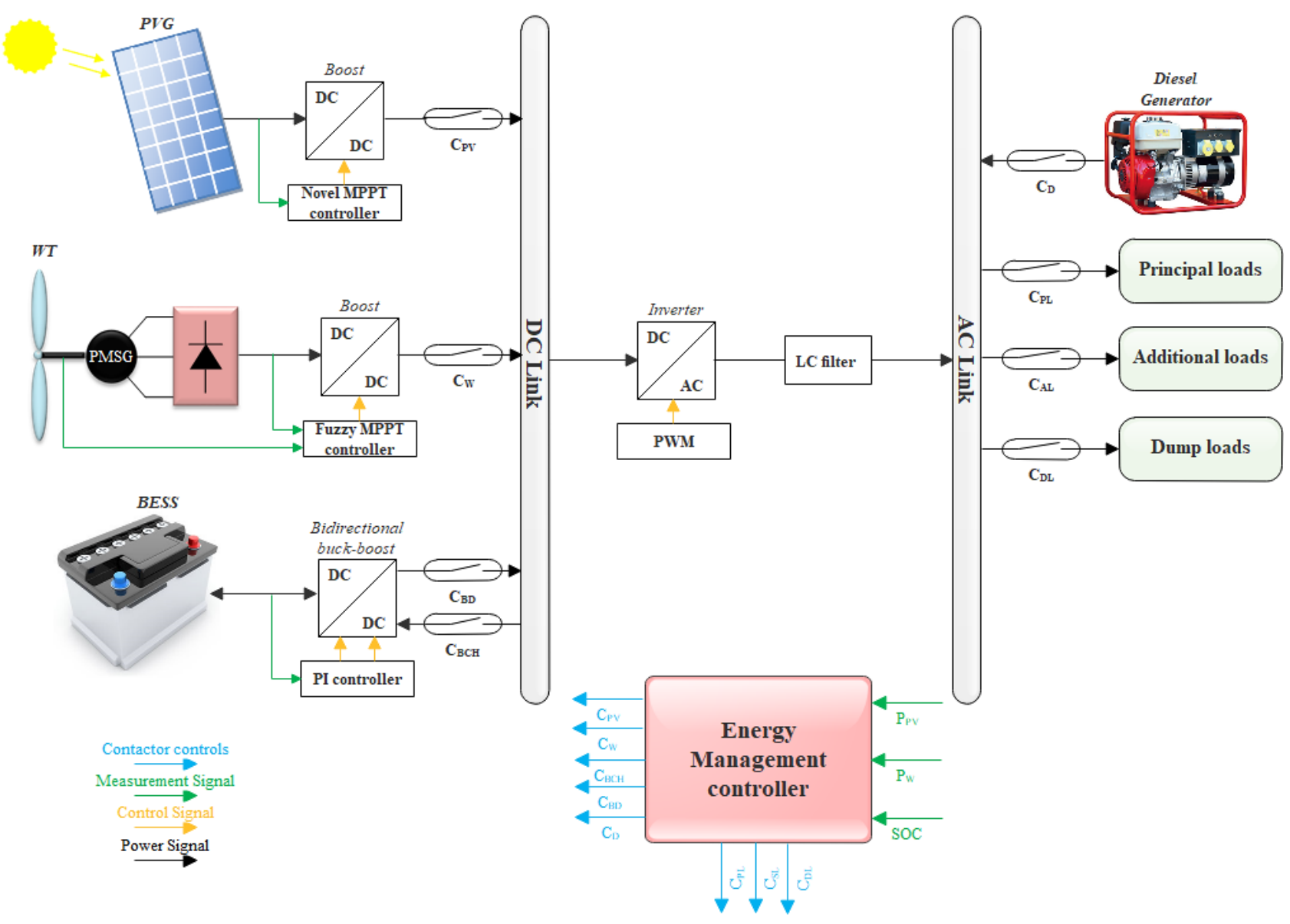

Figure 1. Configuration of the IHPS.

The PVS includes a PV array and a novel MPPT controller. This is implemented to maximize the generated power of the PV system, by adjusting the duty cycle of the boost converter. The WECS is configured by a variable speed wind turbine (WT), a permanent magnet synchronous generator (PMSG), AC-DC diode bridge uncontrolled rectifier and a stage of DC-DC conversion for MPPT composed by a boost converter controlled by a maximum power point tracking (MPPT) technique, to generate the optimal power from the WT, by modulating the duty cycle.

Energy storage system (ESS) is used to store excess power from RESs and cover the energy deficiency in case of power failure. The ESS consists of a battery bank and a bidirectional DC-DC buck-boost converter associated at the DC-link of the IHPS and controlled through a PI control cascade strategy, to keep the DC bus voltage constant at the desired level, despite the power changes between the RESs and loads. The constant DC voltage obtained from the two RESs systems and ESS is inverted by a PWM VSI and supplied to AC load via an LC filter to get sinusoidal current.

A diesel generator is connected to the AC bus system to supply directly the principal loads when the energy requirement exceeds the total energy produced by the RESs and Battery ESS. A supervisor is developed in this work to supervise the power flows between the devices of the IHPS and ensure electrical supply continuity for the loads. 


\section{3- Modelling of the IHPS}

\section{3-1- Modelling of PVS}

\section{3-1-1- Modelling of PV Cell and PV Generator}

Solar cells are composed of a p-n junction fabricated by differently doped semiconductor materials [5]. Thereby the solar cell can be presented by a simple circuit consisting of a current source IPH represents the cell photocurrent, in parallel with a diode $\mathrm{D}$ which used to represent the nonlinear impedance of the p-n junction, RS and RSH is the series and shunt resistance respectively. The model of the solar cell used in this research work is shown in Figure 2 [6, 7].

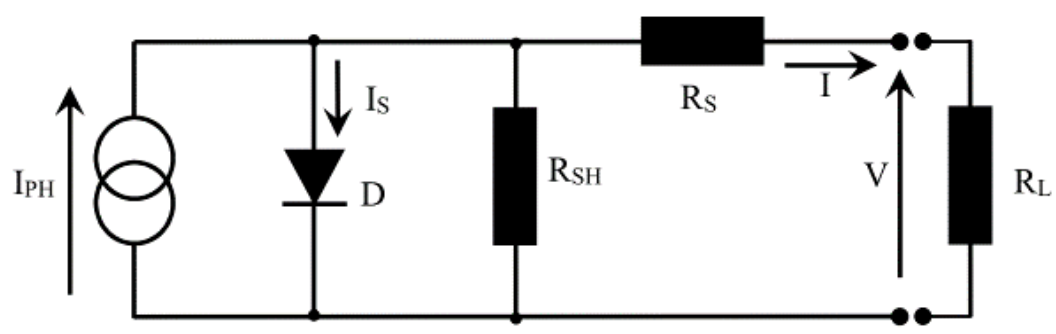

Figure 2. Equivalent circuit model of PV cell.

The output current I of the cell can be modelled mathematically by the following equations:

$\mathrm{I}=\mathrm{I}_{\mathrm{PH}}-\mathrm{I}_{\mathrm{S}} \cdot\left(\exp \left(\frac{\mathrm{q} \cdot\left(\mathrm{V}+\mathrm{R}_{\mathrm{S}} \mathrm{I}\right)}{\alpha \cdot \mathrm{k} \cdot \mathrm{T}}\right)-1\right)-\frac{\mathrm{V}+\mathrm{R}_{\mathrm{S}} \mathrm{I}}{\mathrm{R}_{\mathrm{SH}}}$

Where; I: Solar cell current (A), V: Solar cell output voltage (V), I $\mathrm{PH}_{\mathrm{PH}}$ : Solar generated current (A), Is: Diode saturation current (A), $R_{S}$ : Solar cell series resistance $(\Omega)$, $R_{S H}$ : Solar cell shunts resistance $(\Omega)$, $\alpha$ : Ideality factor (between 1 and 2), k: Boltzmann constant $\left(1.38 \times 10^{-23} \mathrm{~J} / \mathrm{K}\right)$, T: Cell temperature in Kelvin $(\mathrm{K})$.

The PV cell presents a voltage current and power-current nonlinear characteristic which depend on mainly of insolation and temperature. To obtain the desired high power, PV cells are associated in series and parallel circuits on PV modules. These modules can be also regrouped in series and/or parallel to form the PV generator (PVG). Based on the PV cell model, the model of a PVG with NS $\times$ NP cells is represented as follows:

$I_{P V G}=N_{P} \cdot I_{P H}-N_{P} \cdot I_{S} \cdot\left(\exp \left(\frac{q \cdot\left(U_{P V G}+R_{S G} \cdot I_{P V G}\right)}{N_{S} \cdot \alpha \cdot k \cdot T}\right)-1\right)-\frac{U_{P V G}+R_{S G} \cdot I_{P V G}}{R_{S H G}}$

Where $\mathrm{N}_{S}$ and $\mathrm{N}_{\mathrm{P}}$ are the numbers of PV cellules connected in serial and parallel, respectively.

\section{3-1-2- MPPT for PV System}

To ensure the optimization of the efficiency of the PVS, MPPT technique in designed to control a static converter between the load and the PVG to extract the maximum power points (MPP) during the variation of the load, irradiation and temperature, by operating the PVG at optimum voltage and current. There are many MPPT methods existing in the literature. The most used in the photovoltaic sector is the $\mathrm{P} \& \mathrm{O}$ algorithm. Its principle consists essentially in perturbing the output voltage of the PVG by acting on the duty cycle. Indeed, as a consequence of this perturbation, the algorithm calculate the power supplied by the PVG at instant k to the previous one at instant $(\mathrm{k}-1)$. If the power increases, the algorithm approach the MPP and the variation of the duty cycle is maintained in the same direction.

On the contrary, if the power decreases, the algorithm move away from the MPP. Then, it must reverse the direction of the variation of the duty cycle. The research theoretically stops when the system achieves the MPP. A major shortcoming of the algorithm $\mathrm{P} \& \mathrm{O}$ is the bad behavior resulting from a sudden change in irradiation (clouds). For this reason, a novel control strategy is developed in this work, which allows a good tracking of the MPP, despite the variations of climatic conditions with a fast response (in section 4).

\section{3-2-WECS Modelling}

\section{3-2-1- Wind Turbine Model}

The output mechanical power extracted by the wind turbine is expressed as given by [8-10]:

$\mathrm{P}_{\mathrm{m}}=\frac{1}{2} \cdot \mathrm{C}_{\mathrm{P}} \cdot \rho \cdot \mathrm{S} \cdot \mathrm{V}_{\mathrm{w}}{ }^{3}$

Where: Pm Mechanical Power $(W), \mathrm{S}$ is the wind turbine rotor swept area $\left(\mathrm{m}^{2}\right), \mathrm{V}_{\mathrm{w}}$ is the wind speed $(\mathrm{m} / \mathrm{s}), \rho$ is air density $\left(\mathrm{kg} / \mathrm{m}^{3}\right), C_{p}$ is the power coefficient. 
In case of power regulation, the coefficient $C_{P}$ is considered as an important parameter. It's the ratio of the mechanical power to the power offered by the wind. Each turbine type has a unique non-linear function of $C_{P}$. The power coefficient used in this work is defined as a function of $\lambda$ and $\beta$, which are respectively the tip speed ratio and the blade pitch angle:

$C_{P}(\lambda, \beta)=C_{1}\left(\frac{C_{2}}{\lambda_{i}}-C_{3} \cdot \beta-C_{4}\right) e^{-\frac{C_{5}}{\lambda_{i}}}+C_{6} \cdot \lambda$

With:

$\frac{1}{\lambda_{\mathrm{i}}}=\frac{1}{\lambda+0,08 \cdot \beta}-\frac{0,035}{\beta^{3}+1}$

The coefficients $\mathrm{C}_{1}$ to $\mathrm{C}_{6}$ are: $\mathrm{C}_{1}=0.5176, \mathrm{C}_{2}=116, \mathrm{C}_{3}=0.4, \mathrm{C}_{4}=5, \mathrm{C}_{5}=21$ and $\mathrm{C}_{6}=0.0068$.

The tip speed ration $\lambda$ is defined as the ratio between the speed of the tips of the blades of a wind turbine and the speed of the wind.

$\lambda=\frac{W_{\mathrm{m}} \cdot \mathrm{R}}{\mathrm{V}_{W}}$

Where: $R$ is radius of the rotor $(\mathrm{m})$ and $W_{m}$ is the mechanical angular velocity of the generator $(\mathrm{rad} / \mathrm{sec})$.

Figure 3 presents the $C_{p}$ characteristics of the wind turbine used in this work, for different values of $\beta$.

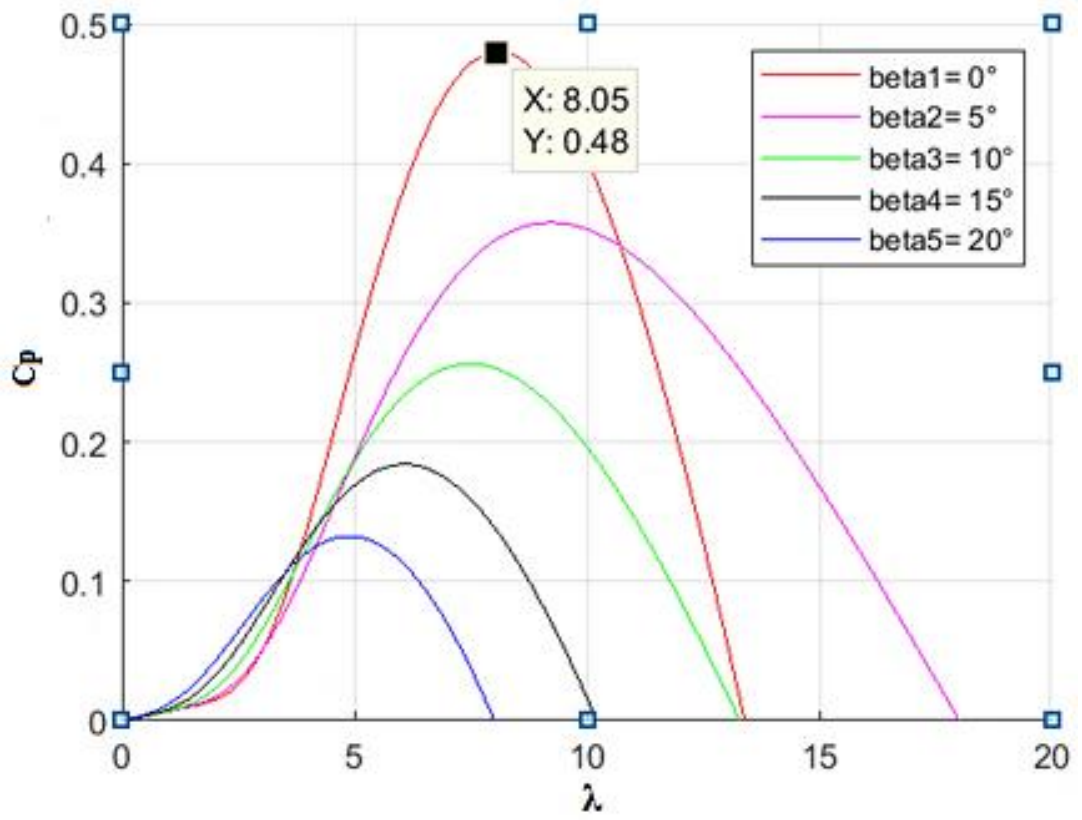

Figure 3. Cp- $\lambda$ characteristics, for different values of the pitch angle $\beta$.

The maximum value of $\mathrm{C}_{\mathrm{p}}\left(\mathrm{C}_{\mathrm{pmax}}=0,48\right)$ is attained for $\beta=0^{\circ}$ and for $\lambda_{\text {opt }}=8,1$. This nominal value of $\lambda$ allows obtaining maximum power for a given wind speed. In this work, the wind turbine has a fixed pitch angle $\beta$ set to zero, in order that it operates in optimal conditions.

\section{3-2-2- Permanent Magnet Synchronous Generator (PMSG) Model}

The dynamic model of PMSG can be represented in the Park's (d, q) system using the following equations:

$\left[\begin{array}{c}\mathrm{V}_{\mathrm{d}} \\ \mathrm{v}_{\mathrm{q}}\end{array}\right]=-\left[\begin{array}{cc}\mathrm{R}_{\mathrm{s}} & 0 \\ 0 & \mathrm{R}_{\mathrm{s}}\end{array}\right]\left[\begin{array}{c}\mathrm{I}_{\mathrm{d}} \\ \mathrm{I}_{\mathrm{q}}\end{array}\right]-\left[\begin{array}{cc}\mathrm{L}_{\mathrm{d}} & 0 \\ 0 & \mathrm{~L}_{\mathrm{q}}\end{array}\right] \frac{\mathrm{d}}{\mathrm{dt}}\left[\begin{array}{c}\mathrm{I}_{\mathrm{d}} \\ \mathrm{I}_{\mathrm{q}}\end{array}\right]-\mathrm{W}_{\mathrm{e}}\left[\begin{array}{cc}0 & -\mathrm{L}_{\mathrm{q}} \\ \mathrm{L}_{\mathrm{d}} & 0\end{array}\right]\left[\begin{array}{c}\mathrm{I}_{\mathrm{d}} \\ \mathrm{I}_{\mathrm{q}}\end{array}\right]+\mathrm{W}_{\mathrm{e}}\left[\begin{array}{c}0 \\ \Psi_{\mathrm{m}}\end{array}\right]$

Where $R_{s}$ is the stator resistance $(\Omega), L_{d}$ and $L_{q}$ are the inductances $(H)$ of the generator on the $\mathrm{d}$ and q axis respectively, $\psi_{\mathrm{m}}$ is the permanent magnetic flux $\left(W_{b}\right)$ and $W_{e}$ is the electrical rotating speed $(\mathrm{rad} / \mathrm{s})$ of the generator, defined by:

$\mathrm{W}_{\mathrm{e}}=\mathrm{P} \times \mathrm{W}_{\mathrm{m}}$

Where $\mathrm{P}$ is the number of generator pole pairs.

The electromagnetic torque equation is given by:

$\mathrm{C}_{\mathrm{em}}=\frac{3}{2} \mathrm{p}\left[\left(\mathrm{L}_{\mathrm{d}}-\mathrm{L}_{\mathrm{q}}\right) \mathrm{I}_{\mathrm{d}} \mathrm{I}_{\mathrm{q}}-\Psi_{\mathrm{m}} \mathrm{I}_{\mathrm{q}}\right]$ 


\section{3-2-3- Maximum Power Transfer Control Technique}

In case of the WECS, the MPPT controller permit to pursuing the maximum wind generation power under variation of wind speed, by adjusting the rotor speed. According to the Equations 3 and 4, it can be seen that if the rotor speed is kept constant, then any change in wind speed will change the tip-speed ratio, leading to change of $C_{p}$ as well as the output wind turbine power. So the maximum output wind turbine power is produced when the turbine operates at $C_{p m a x}$. For that, the rotor speed should be kept at the optimum value of the tip speed ratio $\lambda_{\text {opt }}$. The expression of the optimum power from a wind turbine is given as:

$\mathrm{P}_{\mathrm{m}_{\mathrm{opt}}}=\frac{1}{2} \cdot \rho \cdot \mathrm{C}_{\mathrm{Pmax}} \cdot \mathrm{S} \cdot\left(\frac{\mathrm{R} \cdot \Omega_{\mathrm{m}}}{\lambda_{\mathrm{opt}}}\right)^{3}$

Where:

$\Omega_{\mathrm{m}_{\mathrm{opt}}}=\frac{\lambda_{\mathrm{opt}} \cdot \mathrm{V}_{\mathrm{V}}}{\mathrm{R}}$

Therefore, the optimum torque can be given by:

$\mathrm{C}_{\mathrm{m}_{\mathrm{opt}}}=\mathrm{K}_{\mathrm{opt}} \cdot \Omega_{\mathrm{mopt}}{ }^{2}$

Where:

$\mathrm{K}_{\mathrm{opt}}=\frac{1}{2} \cdot \rho \cdot \mathrm{C}_{\mathrm{Pmax}} \cdot \mathrm{S} \cdot\left(\frac{\mathrm{R}}{\lambda_{\mathrm{opt}}}\right)^{3}$

Figure 4 shows the characteristics of mechanical rotor power as a function of the rotor speed for different values of wind speed. From this figure, we can conclude that for any wind speed, there is a corresponding rotor speed which allows to achieve the optimal power $P_{\text {mopt }}$

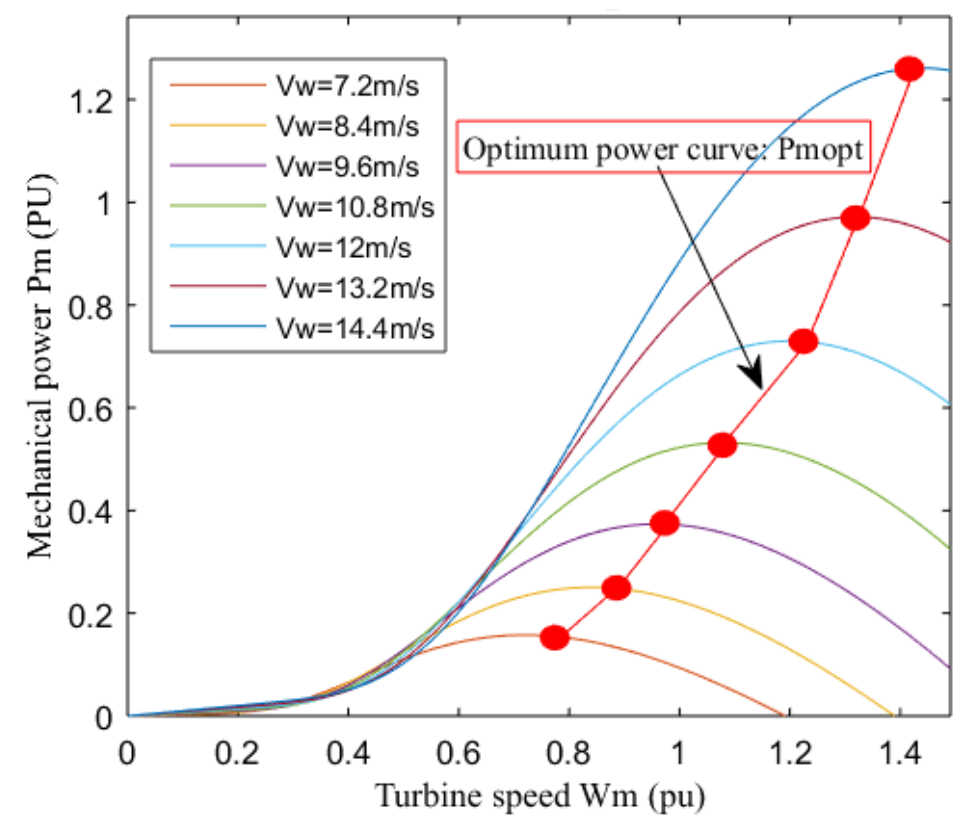

Figure 4. Turbine Power Characteristics (Pitch angle beta $=0^{\circ}$ ).

If we ignore the friction of the rotor, turbine mechanical properties can be expressed by the following equation:

$\frac{\mathrm{dW}}{\mathrm{dt}}=\frac{1}{\left(\mathrm{~J}_{\mathrm{t}}+\mathrm{J}_{\mathrm{g}}\right)} \cdot\left(\mathrm{C}_{\mathrm{m}}-\mathrm{C}_{\mathrm{em}}\right)$

Where $\mathrm{C}_{\mathrm{em}}$ is electromagnetic torque of the PMSG and $\mathrm{J}$ is combined inertia of rotor and turbine. Therefore, in order to produce maximum power for any wind speed, the $\mathrm{C}_{\mathrm{em}}$ of the PMSG is controlled to match with the wind optimum turbine $\mathrm{C}_{\text {mopt }}$ according to rotor speed.

\section{3-3-Energy Storage System Modelling}

A storage battery is an electrical generator formed by a combination of several cells constituted of positive and negative electrodes joined by an electrolyte, these cells use the electrochemical properties of an oxidant-reluctant pair and convert chemical energy into electrical energy [4]. The storage modelling is based on equivalent circuit presented in Figure 5. It is composed by a voltage generator, an internal resistor and a capacity [11]. 


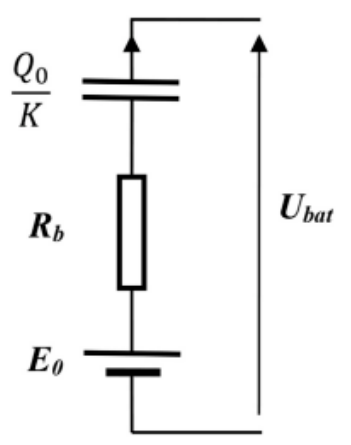

Figure 5. Electrical model of the battery.

Therefore, the mathematical battery model can be written as:

$\mathrm{U}_{\text {bat }}=\mathrm{E}_{0}-\left(\mathrm{K} \cdot \frac{\int \mathrm{I}_{\mathrm{b}} d t}{\mathrm{Q}_{0}}\right)-\mathrm{R}_{\mathrm{b}} \cdot \mathrm{I}_{\mathrm{b}}$

Where: $E_{0}$ : Empty voltage of the charged battery $(\mathrm{V}), \mathrm{K}$ : Constant depends on the battery, $\mathrm{R}_{\mathrm{b}}$ : Internal resistance of the battery $(\Omega), \mathrm{I}_{\mathrm{b}}$ : Battery current positive while discharging and negative while charging $(\mathrm{A}), \frac{\int \mathrm{I}_{\mathrm{b}} d t}{\mathrm{Q}_{0}}$ : Indicates the discharge status of the battery, $Q_{0}$ : Capacity of the battery $(A h), U_{\text {bat }}$ : Battery output voltage $(\mathrm{V})$.

The state of charge (SOC) is an essential parameter for managing the energy flow between the IHPS and the load demand. It is calculated by the following expressions [12]:

$\mathrm{SOC}=100 \cdot\left(1+\frac{\int \mathrm{I}_{\mathrm{b}} d t}{\mathrm{Q}_{0}}\right)$

The energy constraints of the battery are limited between two values $\mathrm{SOC}_{\min }$ (minimal state of charge) and $\mathrm{SOC}_{\max }$ (maximal state of charge), to ensure the performance of the energy management [13].

\section{3-4-Diesel Generator}

A diesel generator (DG) consists of an internal combustion (IC) engine coupled to a synchronous generator. The schematic diagram of DG is shown in following figure:

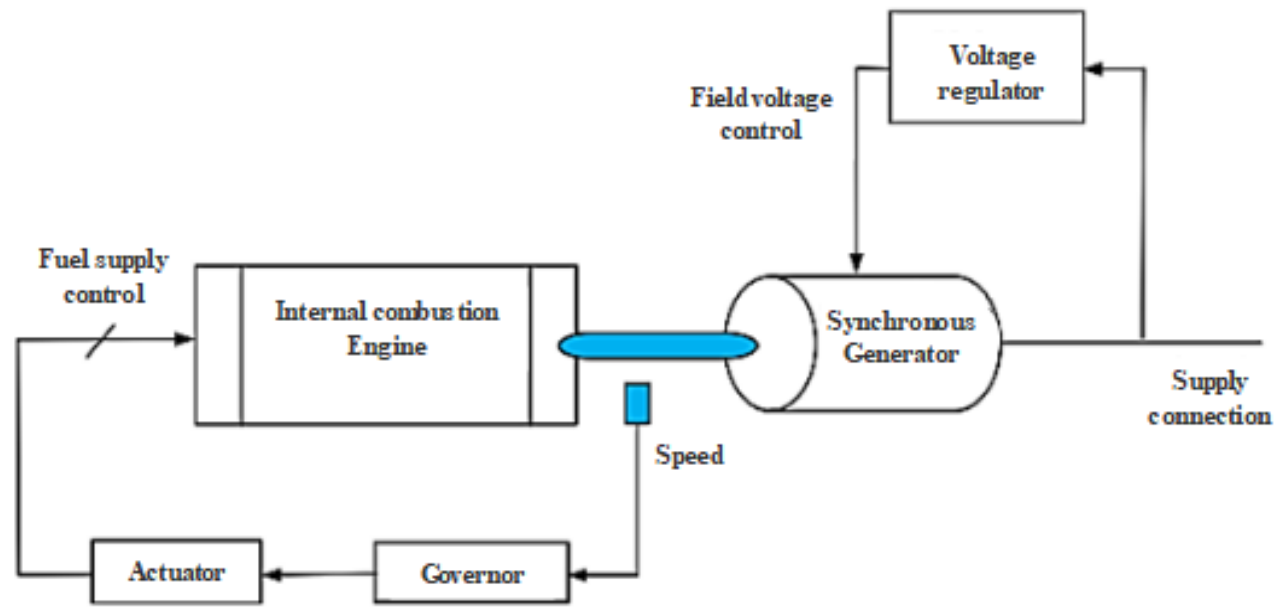

Figure 6. Schematic diagram of the diesel generator.

The IC engine is integrated with a governor to control the output speed of the engine shaft in order to control the generator frequency. The governor adjusts the fuel to the engine as required to keep the engine operating at the desired speed. The synchronous generator uses a combination exciter-Voltage Regulation system. The voltage regulator control is designed to regulate generator output terminal voltage [14].

\section{4- Power Electronics Interfaces Control}

\section{4-1-Boost Converter and Fuzzy MPPT Controller}

In this work, a boost converter is implemented to be controlled by MPPT technique, in both PVS and WECS [5]. In Case of PVS, a novel control strategy has been designed for a boost converter, to achieve maximum efficiency. The structure of the proposed MPPT control strategy is shown in the following figures: 
(a)
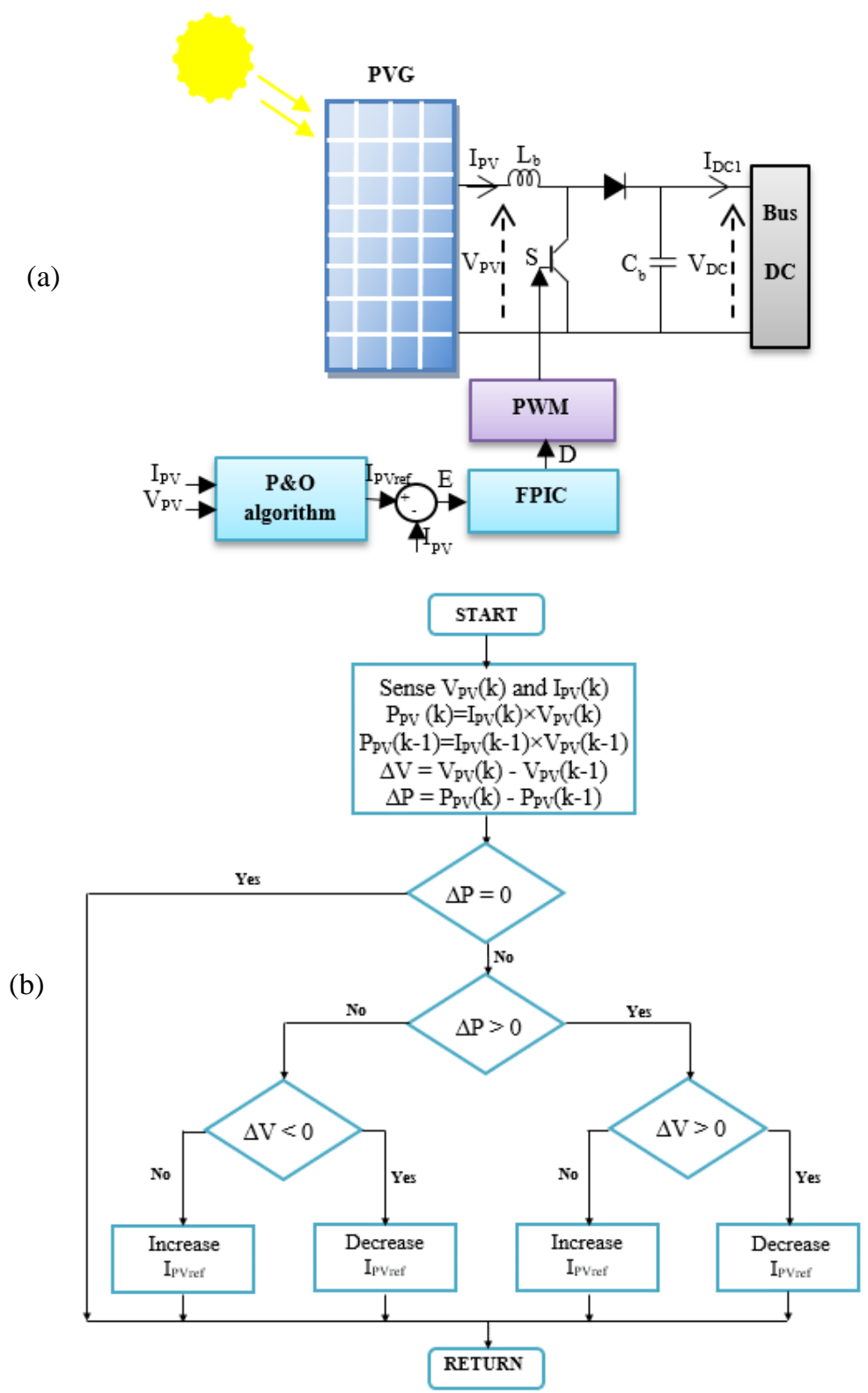

Figure 7. (a) Novel MPPT control for PVS; (b) P\&O algorithm flowchart.

The proposed control structure is based on measuring the output current and voltage of the PVG, then a perturbation and observation (P\&O) algorithm with current step is executed to calculate the reference current IPVref. The error between the reference current and the measured current is the input of a FPIC, which generates the duty cycle that allows to reach the maximum power points of the PVS. This proposed MPPT controller is tested and compared with the classical P\&O algorithm to verify its capacity to track the maximal power points $\mathrm{P}_{\text {Mref }}$ and its robustness, under disturbed irradiance variation, as shown in following simulation results:

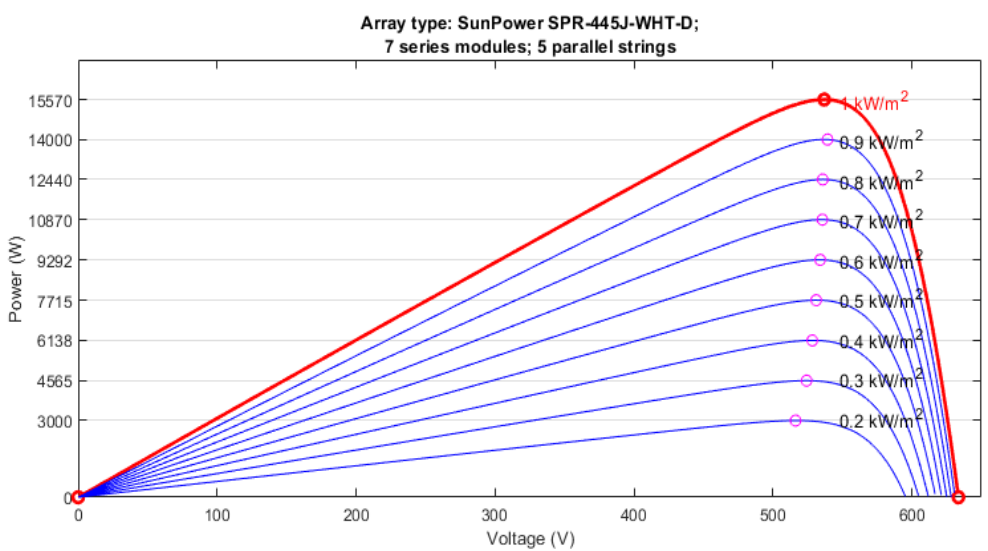



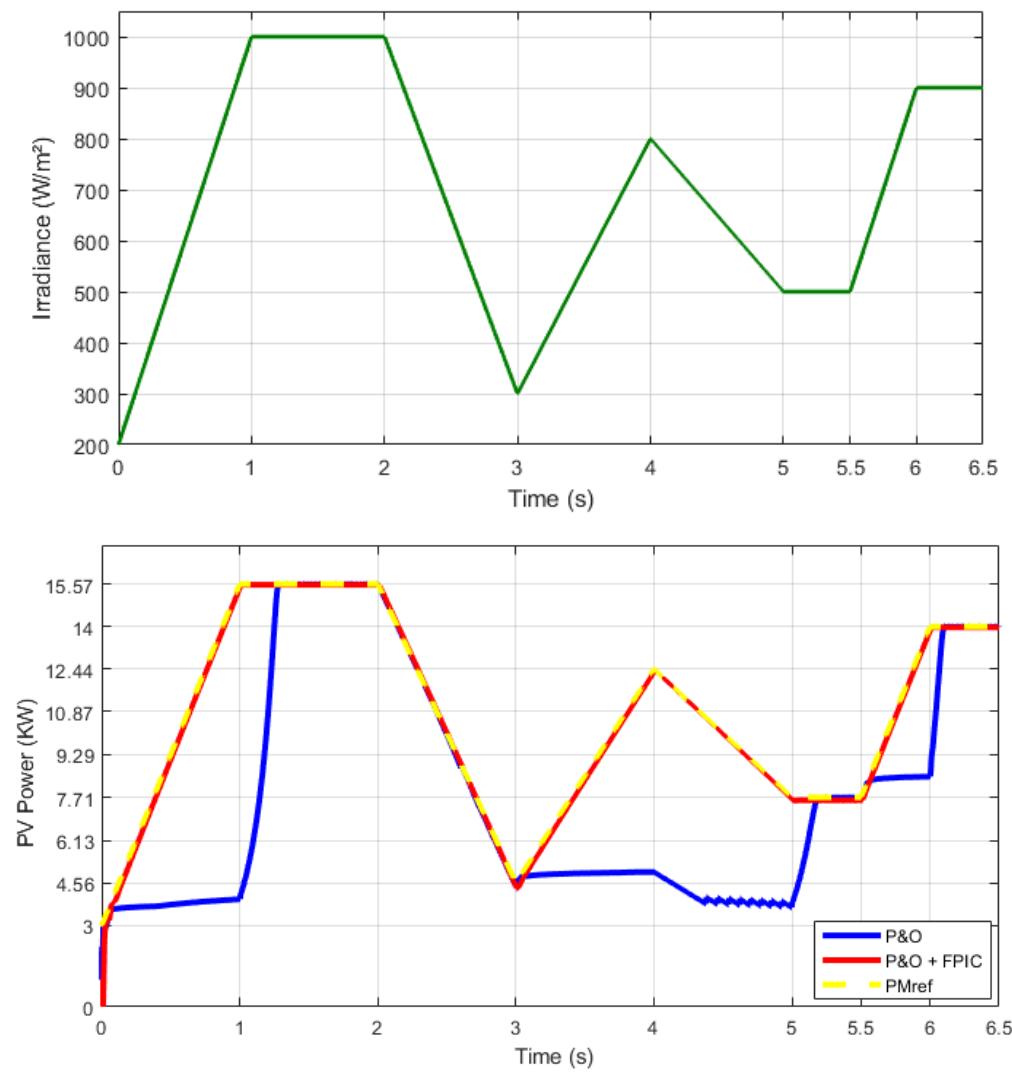

Figure 8. Simulation results of the proposed MPPT control strategy for the PVS.

According to the previous curves, we notice that the proposed MPPT control strategy track instantly the maximum power points during fast variations of irradiance with more stability and accuracy, compared to the classical $\mathrm{P} \& \mathrm{O}$ algorithm, which has a bad tracking of $\mathrm{P}_{\text {Mref }}$ in the transient state. In case of WECS, the structure of the proposed MPPT control strategy is shown in the following figures:
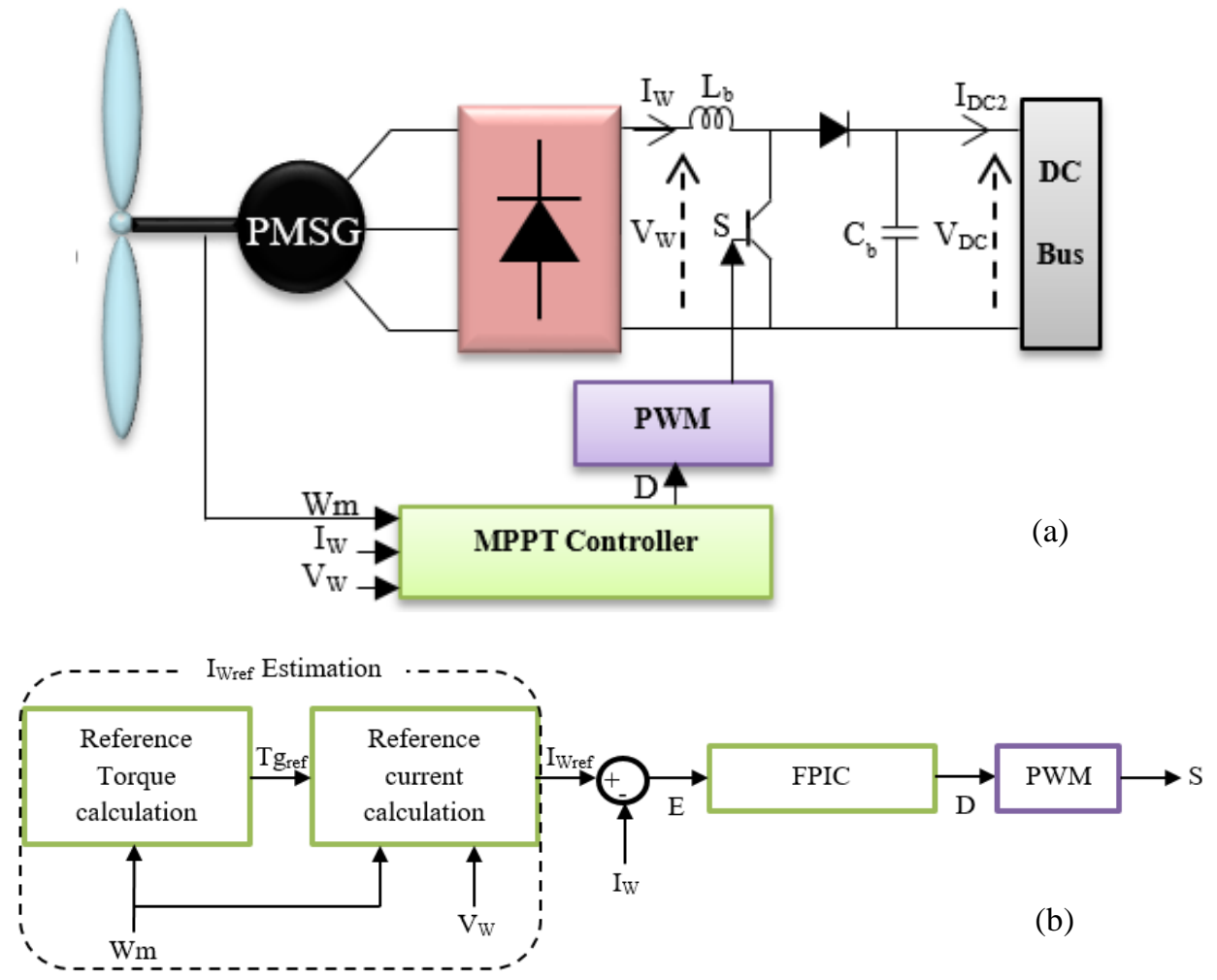

Figure 9. (a) Block diagram of the WECS; (b) Structure of MPPT controller for WECS. 
Where:

$\mathrm{T}_{\mathrm{gref}}=\mathrm{K}_{\mathrm{opt}} \cdot \mathrm{W}_{\mathrm{m}}^{2}$

And:

$\mathrm{I}_{\mathrm{ref}}=\frac{\mathrm{T}_{\mathrm{g}_{\mathrm{ref}}} \cdot \mathrm{W}_{\mathrm{m}}}{\mathrm{V}_{\mathrm{W}}}$

Through the FPIC, the error between the reference current $\mathrm{I}_{\mathrm{Wref}}$ and measured current $\mathrm{I}_{\mathrm{W}}$ is used to vary the duty cycle $\mathrm{D}$ for the Boost converter, in order to extract the maximum power point. The Block diagram of FPIC applied in MPPT control loop for both PVS and WECS, is presented in Figure 10.

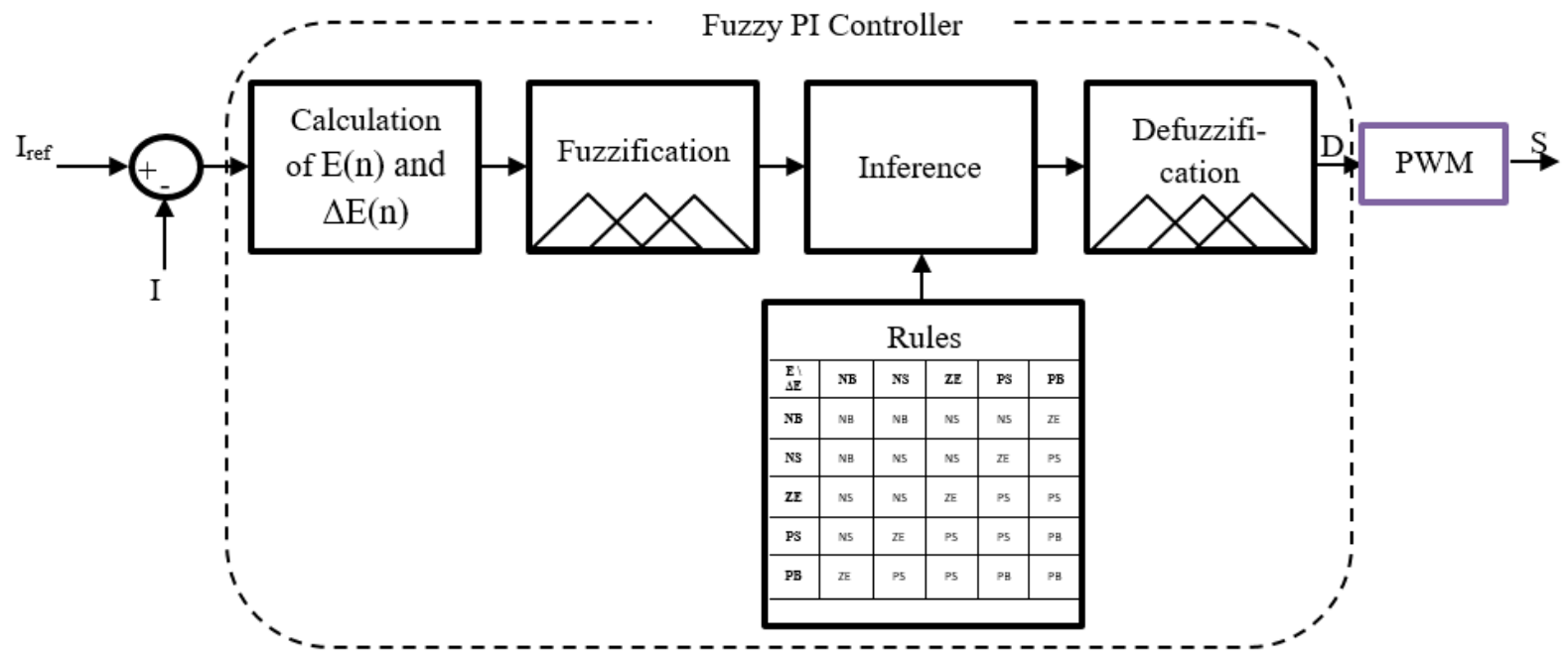

Figure 10. Block diagram of FPIC.

The inputs to a FPIC are usually an error $E(n)$ and a change of error $\Delta E(n)$ as expressed in Equations 19 and 20 respectively.

$\mathrm{E}(\mathrm{n})=\mathrm{I}_{\text {ref }}-\mathrm{I}$

$\Delta \mathrm{E}(\mathrm{n})=\mathrm{E}(\mathrm{n})-\mathrm{E}(\mathrm{n}-1)$

During fuzzification $\mathrm{E}$ and $\Delta \mathrm{E}$ are calculated and converted to the linguistic variables. Then an inference is executed based on a set of rules. Finally, the fuzzy output is converted into a numeric value via defuzzification step. The obtained result is the change of duty cycle of the switch S for the DC-DC boost converter. The simulation results of this MPPT strategy have been presented and described in Tahiri et al. (2019) study [15].

\section{4-2-Bidirectional Buck-boost Converter}

A DC-DC Bidirectional buck-boost converter is connected between the storage battery and the DC-link of the IHPS, in order to keep the DC-link voltage constant despite the power changes in the sources and the loads [16, 17]. A PI control cascade strategy is used to regulate the DC bus voltage as shown in Figure 11 [18].

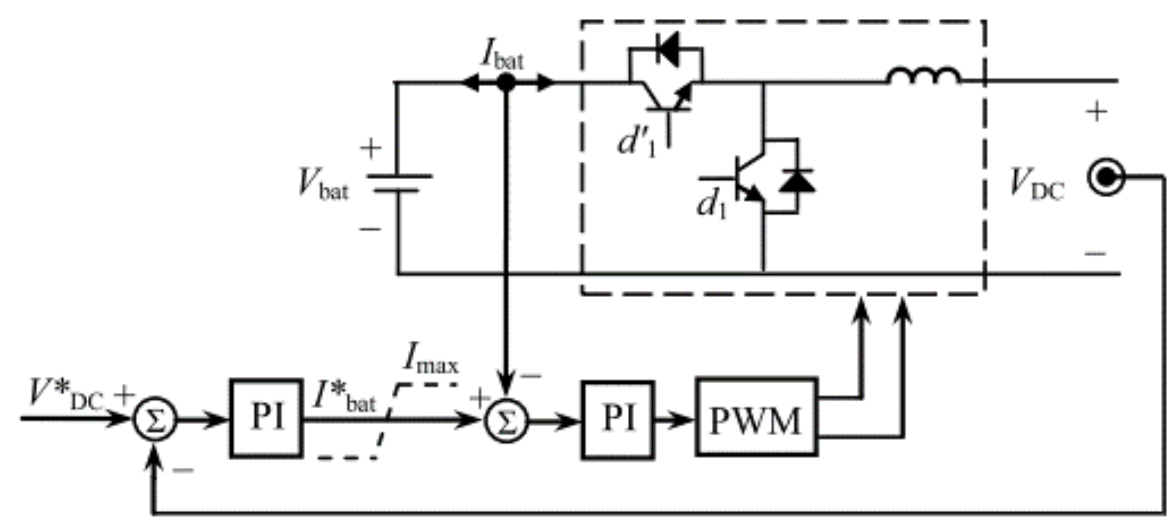

Figure 11. Control structure of bi-directional DC/DC converter. 
The error between the measured output voltage and the reference voltage is the input of the first PI controller. The output of this voltage controlled loop is set as the charging/discharging current reference. In the inner current loop, the reference current signal is compared to the measured current to generate a duty cycle, which can drive the IGBTs through the PWM signal, to regulate the DC bus voltage.

\section{4-3-VSI and Filter Model}

In this work, a sinusoidal PWM inverter is used to convert the DC Voltage into three-phase AC voltage [4]. The power part of the inverter is composed of three arms consisting each one two switches. Each switch is composed of transistor and of a diode coupled in parallel. The LC filter is connected to the inverter output, it's designed to reduce high order harmonics of the voltage and current, produced by the sinusoidal PWM inverters.

\section{6- Energy Management System for IHPS}

The essential role of the supervisory controller is to satisfy the loads demand without interruption under variable weather conditions, by managing the power flow of the IHPS [19-23]. The proposed energy management algorithm uses primarily the power provided by the PVS and WECS to supply the load, and minimizes the use of the batteries and DG for optimizing of fuel consumption and saving the environment.

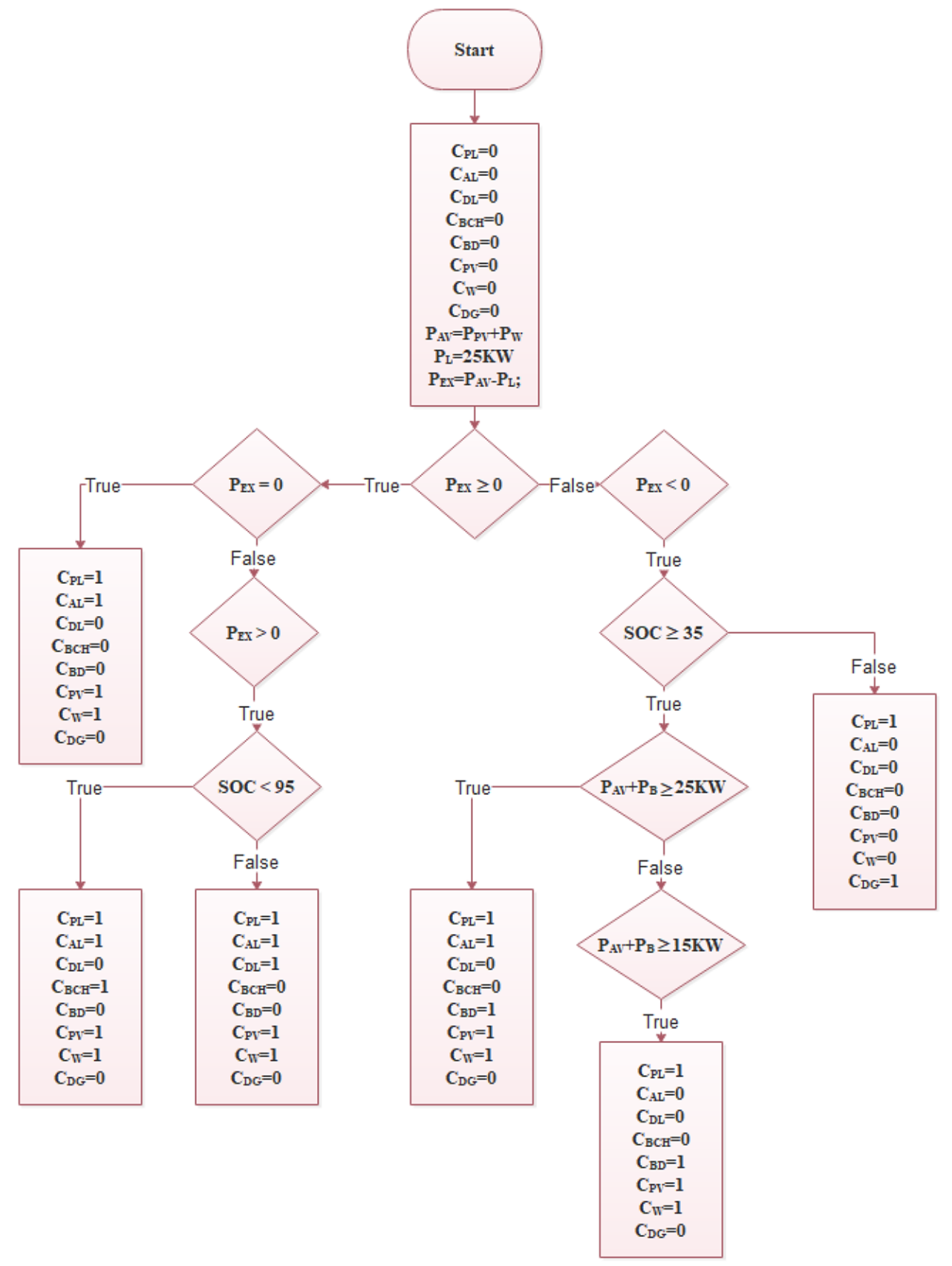

Figure 12. Flowchart of the IHPS management algorithm. 
The management controller generates seven contactors control signals: $\mathrm{C}_{\mathrm{PV}}$ of the PVS, $\mathrm{C}_{\mathrm{W}}$ of the WECS, $\mathrm{C}_{\mathrm{BD}}$ of battery discharging, $\mathrm{C}_{\mathrm{BCH}}$ of battery charging, $\mathrm{C}_{\mathrm{PL}}$ of principal loads, $\mathrm{C}_{\mathrm{AL}}$ of additional loads, $\mathrm{C}_{\mathrm{DL}}$ of dump loads and $\mathrm{C}_{\mathrm{DG}}$ of diesel generator, starting from four inputs: the measured power $\mathrm{P}_{\mathrm{PV}}$ and $\mathrm{P}_{\mathrm{W}}$ respectively from PVS and WECS, power demanded by loads and the battery bank SOC. The supervision algorithm for power management is shown in Figure 12. It can be summarized as follows scenarios:

- Scenario 1: The total power generation from PVS and WECS reaches $25 \mathrm{~kW}$. In this case, the principal and additional loads will be supplied only by RESs.

- Scenario 2: If the RESs energy is greater than the load demand and the SOC is less than 95\%, the excess is used to charge the batteries.

- Scenario 3: If the RESs energy is greater than the load demand and the SOC is not less than $95 \%$, then the supervisory controller connects the dump load.

- Scenario 4: PV and wind energy sources are insufficient to supply loads. In this case the principal and additional loads will be supplied by the RESs and batteries, if SOC is greater than $35 \%$ and total generation power from the sources reaches $25 \mathrm{KW}$.

- Scenario 5: if the total power produced by RESs and batteries reaches just $15 \mathrm{KW}$, supervisory controller disconnects the additional load and supply only the principal loads.

- Scenario 6: In case of PV and wind energy sources is insufficient to supply loads and the SOC is less than $35 \%$, then diesel generator starts to supply only the principal loads.

\section{7- Simulation Results}

The model of the IHPS is designed and simulated with Matlab/Simulink platform, to verify the performance of the proposed power management strategy in different scenarios and under variable weather conditions. In this proposed IHPS, the PVS and the WECS are considered as the main power sources for supplying the energy demand of $30 \mathrm{KW}$ maximum to the load: $15 \mathrm{KW}$ principal load, $10 \mathrm{KW}$ additional load and $5 \mathrm{KW}$ dump load. The batteries and the DG are used as backup systems.

The PVG is composed of 5 strings connected in parallel, each string consists 7 modules connected in series. The output power of the PVG is $15 \mathrm{KW}$ at nominal operating conditions. The rated power of the WT is $25 \mathrm{KW}$. The ESS consists of 34 batteries of $150 \mathrm{AH}$ connected in series, which can provide $61.2 \mathrm{KWH}$ and can supply the principal load during 4 hours. The DG is the last backup systems. Its rated power is $15 \mathrm{KW}$. Table 1 summarizes the parameters of each system.

Table 1. Parameters of IHPS.

\begin{tabular}{ll}
\hline Parameters & Values \\
\hline PVS & $15 \mathrm{KW}$ \\
Power rating & \\
WECS & $25 \mathrm{KW}$ \\
Power rating & \\
ESS & 34 \\
Number of batteries in series & $150 \mathrm{AH}$ \\
Single battery capacity & \\
DG & $15 \mathrm{KW}$ \\
Rated power & \\
Loads & $15 \mathrm{KW}$ \\
Power of principal load & $10 \mathrm{KW}$ \\
Power of additional load & $5 \mathrm{KW}$ \\
Power of dump load & \\
\hline
\end{tabular}

Figures 13.a to 13.e show, respectively the load power, the power generated from PVS, the power generated from WECS and the power of DG. These results verify the availability of the energy for load demand in spite of the insufficient energy produced by RESs. The SOC of batteries increase or decrease depending on the excess power or deficient power generated by the RESs as presented in figure 13.e. The load voltage is maintained within the limit as shown in figure 13.f. The plotted simulation results of the power flow supervisory are shown in follows figures: 
(a)

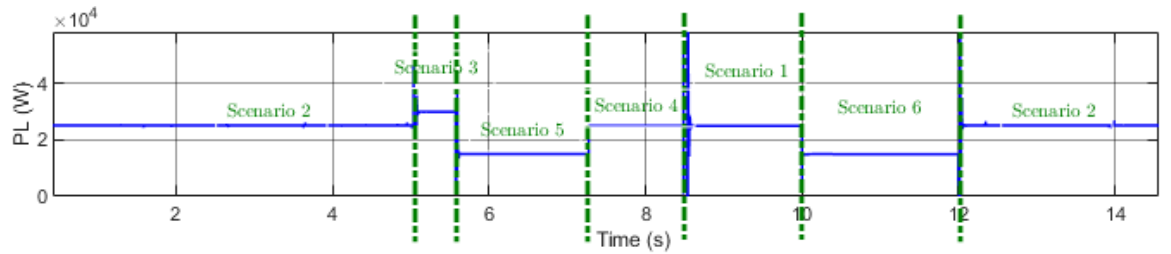

(b)

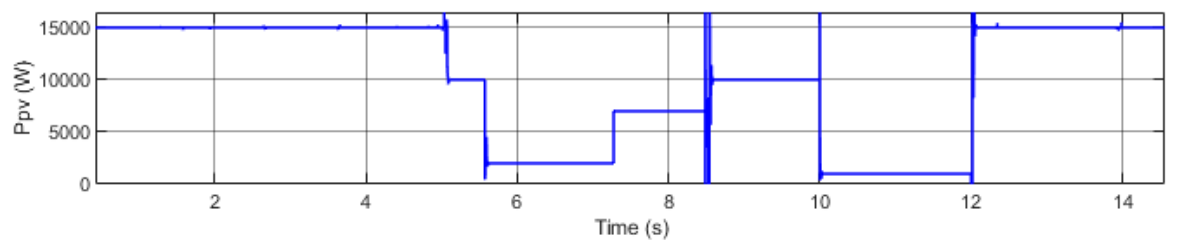

(c)

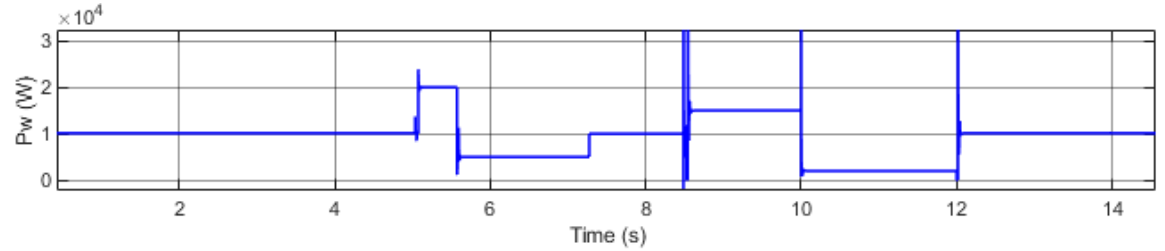

(d)

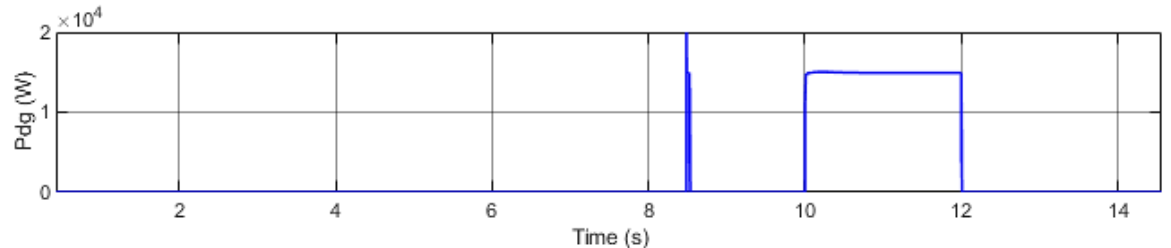

(e)

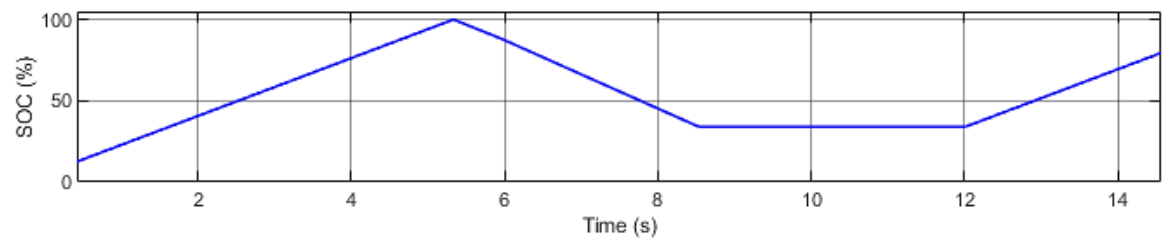

(f)
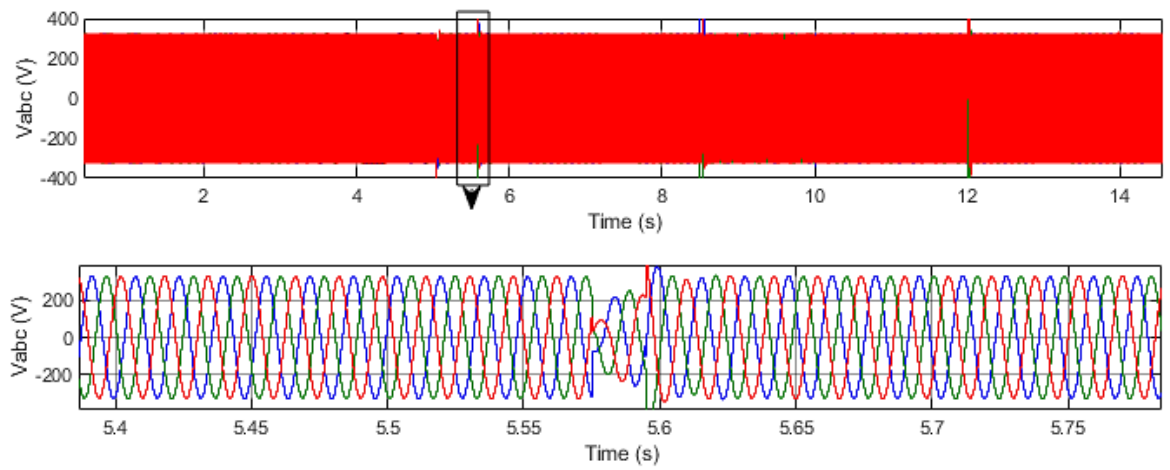

(g)
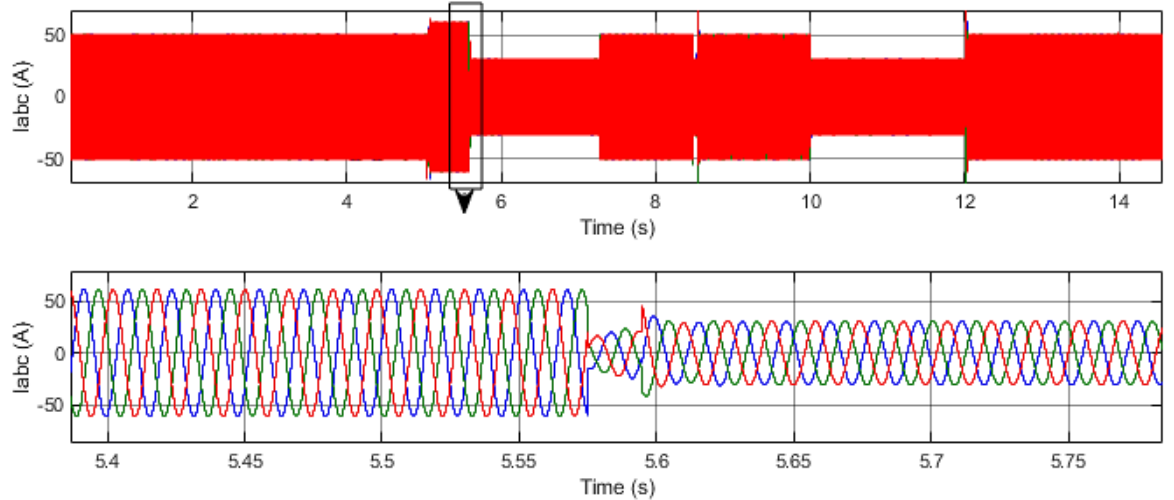

Figure 13. Simulation results of the IHPS. a) Load power (W); b) Power from PVS (W); c) Power from WECS (W); d) Power from DG (W); e) Batteries state of charge (\%);f. Load Voltage (V); g) Load current (A). 
This simulation results show clearly all the possible scenarios described previously in the supervision algorithm. Therefore, the objective of the proposed IHPS's energy management is achieved.

\section{8- Conclusions}

In this work, optimal control strategies of an isolated hybrid Solar-Wind-Battery-Diesel power system has been presented.

- Firstly, and in order to improve the efficiency of RESs, we adopted MPPT controls for both PVS and WECS to generate the optimal power to the load under variable climatic conditions. A novel MPPT strategy, combine between the simplicity of the classical P\&O algorithm and the flexibility of the FPIC, has been developed for the PVS. The simulation results show the robustness of this novel MPPT controller, during rapid change in weather conditions, compared to the classical P\&O algorithm;

- The second part concerns the control of the DC bus voltage to a reference value with the ESS and the control applied to the inverter;

- Finally, an energy management has been established using the switching method and simulated for loads of 30 KW peak. The simulation results showed the electrical production continuity for loads whatever the meteorological conditions, by the optimal interaction of the renewable energy sources with less usage of backup power systems (Batteries + DG).

\section{9- Declarations}

\section{9-1-Author Contributions}

All authors have contributed an equal amount of work to this article. All authors have read and agreed to the published version of the manuscript.

\section{9-2-Data Availability Statement}

The data presented in this study are available on request from the corresponding author.

\section{9-3- Funding}

The authors received no financial support for the research, authorship, and/or publication of this article.

\section{9-4- Conflicts of Interest}

The author declares that there is no conflict of interests regarding the publication of this manuscript. In addition, the ethical issues, including plagiarism, informed consent, misconduct, data fabrication and/or falsification, double publication and/or submission, and redundancies have been completely observed by the authors.

\section{0- References}

[1] Faquir, Sanaa, Ali Yahyaouy, Hamid Tairi, and Jalal Sabor. "Energy Management in a Hybrid PV/wind/battery System Using a Type-1 Fuzzy Logic Computer Algorithm.” International Journal of Intelligent Engineering Informatics 4, no. 3/4 (2016): 229. doi:10.1504/ijiei.2016.080516.

[2] Kumar, P. Satish, R. P. S. Chandrasena, V. Ramu, G. N. Srinivas, and K. Victor Sam Moses Babu. "Energy Management System for Small Scale Hybrid Wind Solar Battery Based Microgrid." IEEE Access 8 (2020): 8336-8345. doi:10.1109/access.2020.2964052.

[3] Habib, Habib Ur Rahman, Shaorong Wang, M. R. Elkadeem, and Mahmoud F. Elmorshedy. "Design Optimization and Model Predictive Control of a Standalone Hybrid Renewable Energy System: A Case Study on a Small Residential Load in Pakistan." IEEE Access 7 (2019): 117369-117390. doi:10.1109/access.2019.2936789.

[4] Bouchebbat, Rochdi, and Sofiane Gherbi. "A Novel Optimal Control and Management Strategy of Stand-Alone Hybrid PV/Wind/Diesel Power System." Journal of Control, Automation and Electrical Systems 28, no. 2 (November 21, 2016): 284296. doi:10.1007/s40313-016-0290-y.

[5] Tahiri, Fatima-Ezzahra, Khalid Chikh, and Mohamed Khafallah. "Modeling and Performance Analysis of a Solar PV Power System Connected to a Three Phase Load Under Irradiation and Load Variations." Green Energy and Technology (December 25, 2018): 1-23. doi:10.1007/978-981-13-1945-7_1.

[6] Karami, Nabil, Nazih Moubayed, and Rachid Outbib. "Energy Management for a PEMFC-PV Hybrid System." Energy Conversion and Management 82 (June 2014): 154-168. doi:10.1016/j.enconman.2014.02.070.

[7] Bartolucci, Lorenzo, Stefano Cordiner, Vincenzo Mulone, Vittorio Rocco, and Joao Luis Rossi. "Hybrid Renewable Energy Systems for Renewable Integration in Microgrids: Influence of Sizing on Performance.” Energy 152 (June 2018): 744-758. doi:10.1016/j.energy.2018.03.165. 
[8] Tahiri, Fatima Ezzahra, Khalid Chikh, and Mohamed Khafallah. "Designing a Fuzzy-PI Controller of a Stand-Alone Wind Energy Conversion System for MPPT." Lecture Notes in Intelligent Transportation and Infrastructure (2019): 1093-1106. doi:10.1007/978-3-030-11196-0_89.

[9] Mohammed, Omar, Yassine Amirat, and Mohamed Benbouzid. "Economical Evaluation and Optimal Energy Management of a Stand-Alone Hybrid Energy System Handling in Genetic Algorithm Strategies.” Electronics 7, no. 10 (October 4, 2018 ): 233. doi:10.3390/electronics7100233.

[10] Maican, E., V. Vlădut, C. Vîlcu, C. Sorică, M. Dorian, D.P. Mirea, R. Bogăţeanu, et al. "Hybrid Renewable Energy Systems For Isolated Farms. A Review.” Inmateh Agricultural Engineering 59, no. 3 (December 31, 2019): 77-92. doi:10.35633/inmateh59-09.

[11] Roumila, Zoubir, Djamila Rekioua, and Toufik Rekioua. "Energy Management Based Fuzzy Logic Controller of Hybrid System Wind/photovoltaic/diesel with Storage Battery.” International Journal of Hydrogen Energy 42, no. 30 (July 2017): 19525-19535. doi:10.1016/j.ijhydene.2017.06.006.

[12] Merabet, Adel, Khandker Tawfique Ahmed, Hussein Ibrahim, Rachid Beguenane, and Amer M. Y. M. Ghias. "Energy Management and Control System for Laboratory Scale Microgrid Based Wind-PV-Battery.” IEEE Transactions on Sustainable Energy 8, no. 1 (January 2017): 145-154. doi:10.1109/tste.2016.2587828.

[13] Saib, S., A. Gherbi, R. Bayindir, and A. Kaabeche. "Multi-Objective Optimization of a Hybrid Renewable Energy System with a Gas Micro-Turbine and a Storage Battery.” Arabian Journal for Science and Engineering 45, no. 3 (August 5, 2019): 15531566. doi:10.1007/s13369-019-04066-4.

[14] Luu, Ngoc An. "Control and management strategies for a microgrid." PhD diss., Université de Grenoble, (2014): 197.

[15] Tahiri, F. E., K. Chikh, and M. Khafallah. "Commande MPPT utilisant un contrôleur PI-Flou appliqué à un système photovoltaïque autonome." Revue De L'entrepreneuriat Et De L'innovation 2, no. 7 (2019).

[16] Madaci, Bouthaina, Rachid Chenni, Erol Kurt, and Kamel Eddine Hemsas. "Design and Control of a Stand-Alone Hybrid Power System.” International Journal of Hydrogen Energy 41, no. 29 (August 2016): 12485-12496. doi:10.1016/j.ijhydene.2016.01.117.

[17] Hu, Jiefeng, Yinliang Xu, Ka Wai Cheng, and Josep M. Guerrero. “A Model Predictive Control Strategy of PV-Battery Microgrid under Variable Power Generations and Load Conditions.” Applied Energy 221 (July 2018): 195-203. doi:10.1016/j.apenergy.2018.03.085.

[18] Al-Ammar, Essam A., Habib Ur Rahman Habib, Kotb M. Kotb, Shaorong Wang, Wonsuk Ko, Mahmoud F. Elmorshedy, and Asad Waqar. "Residential Community Load Management Based on Optimal Design of Standalone HRES with Model Predictive Control.” IEEE Access 8 (2020): 12542-12572. doi:10.1109/access.2020.2965250.

[19] Bogaraj, T., J. Kanakaraj, and J. Chelladurai. "Modeling and Simulation of Stand-Alone Hybrid Power System with Fuzzy MPPT for Remote Load Application.” Archives of Electrical Engineering 64, no. 3 (January 1, 2015). doi:10.2478/aee-20150037.

[20] Torreglosa, J.P., P. García, L.M. Fernández, and F. Jurado. "Hierarchical Energy Management System for Stand-Alone Hybrid System Based on Generation Costs and Cascade Control.” Energy Conversion and Management 77 (January 2014): 514-526. doi:10.1016/j.enconman.2013.10.031.

[21] Islam, Md Aminul, Adel Merabet, Rachid Beguenane, and Hussein Ibrahim. "Power management strategy for solar-wind-diesel stand-alone hybrid energy system." International Journal of Energy and Power Engineering 8, no. 6 (2014): 850-854. do:10.5281/zenodo.1093100.

[22] González - Rivera, Enrique, Raúl Sarrias - Mena, Pablo García - Triviño, and Luis M. Fernández - Ramírez. "Predictive Energy Management for a Wind Turbine with Hybrid Energy Storage System.” International Journal of Energy Research 44, no. 3 (December 19, 2019): 2316-2331. doi:10.1002/er.5082.

[23] Tabanjat, A., M. Becherif, D. Hissel, and H.S. Ramadan. "Energy Management Hypothesis for Hybrid Power System of H 2 /WT/PV/GMT via AI Techniques.” International Journal of Hydrogen Energy 43, no. 6 (February 2018): 3527-3541. doi:10.1016/j.ijhydene.2017.06.085. 